\title{
A Comprehensive Review on Sustainable Industrial Vertical Farming Using Film Farming Technology
}

\author{
Zitian Zhang ${ }^{1}$, Michel $\operatorname{Rod}^{2} \&$ Farah Hosseinian ${ }^{1,3}$ \\ ${ }^{1}$ Food Science, Department of Chemistry, Carleton University, Ottawa, ON, Canada \\ ${ }^{2}$ Faculty of Business, University of New Brunswick, Saint John, NB, Canada \\ ${ }^{3}$ Institute of Biochemistry, Carleton University, Ottawa, ON, Canada \\ Correspondence: Farah Hosseinian, Institute of Biochemistry, Carleton University, Ottawa, ON, Canada. E-mail: \\ farah.hosseinian@carleton.ca
}

Received: November 24, 2020

Accepted: December 15, 2020 Online Published: December 23, 2020

doi:10.5539/sar.v10n1p46

URL: https://doi.org/10.5539/sar.v10n1p46

\begin{abstract}
Rapid population growth is expected to lead to the global population reaching 8.9 billion by 2050 . In order to sustain such population growth, global food production must grow more than $70 \%$ by 2050 . Arable land per capita, however, is on the decline. Vertical farming (VF) provides an enterprising solution to these concerns. VF utilizes stacked levels of growing racks and beds to maximize grow space per square foot of land and typically uses hydroponics to reduce water use. Similarly, film farming (FF) is a new agricultural technique developed in Japan for the soilless cultivation of crops while drastically reducing water use. FF has the potential to be integrated into VF systems to improve water use efficiency, and further improve food safety. This, however, relies on the possible improvements in yield and plant quality to increase sales volume and price to offset the added cost of FF. This review illustrates a cost-benefit analysis of a theoretical VF to show the yield increase and price point needed for FF integration to be viable as $27247 \mathrm{~kg}(43.57 \%)$ and \$9.67/ $\mathrm{kg}$ (26.90\%) respectively. This review also shows the benefits to yield and quality is enough for the integration to be viable.
\end{abstract}

Keywords: controlled environment agriculture, food security, hydromembrane, vertical farming, film farming

\section{Introduction}

The global population is estimated to rise to 8.9 billion by 2050 (United Nations, 2017). Rapid population growth requires a matching growth in food production. Arable land per capita, however, is on the decline (FAO, 2011). As such, there is a need for innovative food cultivation strategies to provide food to the global population while economically using the available space and natural resources.

Vertical farming (VF) is a method of food cultivation that contributes to global food security by maximizing food production per space and resources used.

The profitability of VF operations in Canada was evaluated by Eaves and Eaves (2018). They found the operational costs comparable to conventional greenhouse farming, but gross profit was higher for vertical farming. The start-up costs, however, were largely due to high real estate prices in urban areas as well as high costs in LED lighting (Eaves and Eaves, 2018).

This review aims to explore the feasibility of VF as a local, sustainable food production system. It then evaluates the business viability of VF as well as the viability of integrating new technologies such as film farming to improve to quality of plants being produced.

\section{Vertical Farming Technology}

A typical configuration of a VF system is depicted in figure 1. These vertical farms grow using stacked levels of growing racks or beds to maximize space efficiency (Al-Kodmany, 2018). Most VF systems are lit using solely artificial lighting (Benke and Tomkins, 2017). They are irrigated using drip irrigation, hydroponics, aeroponics and/or aquaponics to use less water (Al-Kodmany, 2018). 


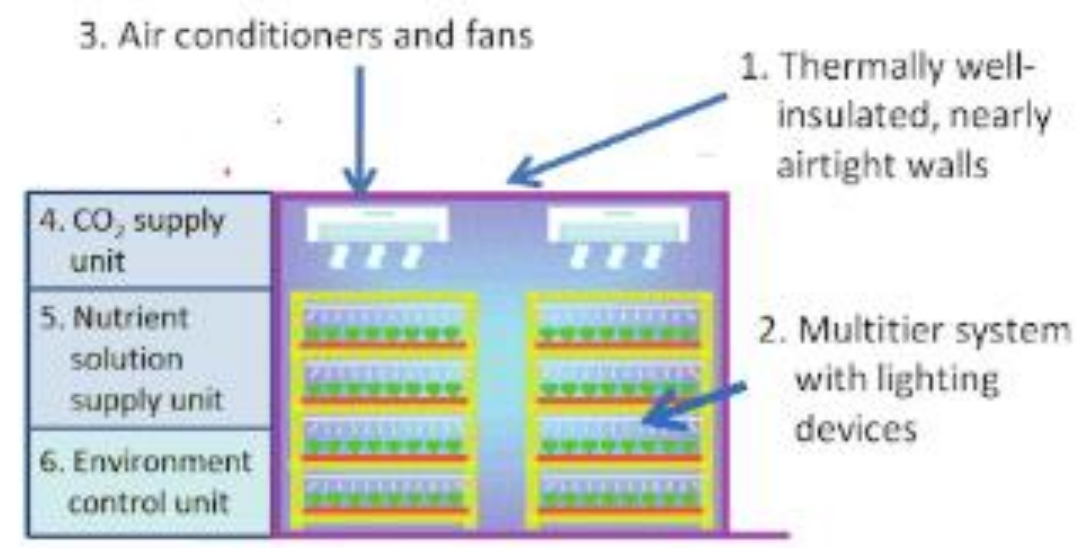

Figure 1. Typical configuration of a VF system. Retrieved from Kozai (2016)

Of the three, hydroponics is the most popular method as aeroponics and aquaponics have higher requirements for maintenance and care.

\subsection{Hydroponics}

Hydroponic systems grow plants by supplying the inorganic ions, nutrients and water via a nutrient solution with or without solid media (Nguyen et al., 2016). Its main advantage is the ability to grow plants without using soil. This makes hydroponically grown produce safer as there is less herbicides and pesticides required. As VF systems are closed and hydroponic systems require no soil, there is no agriculture runoff usually seen with traditional agriculture (Benke and Tomkins, 2017). Furthermore, it makes agriculture accessible anywhere as it no longer requires fertile, arable land.

\section{Demand for Vertical Farming}

\subsection{Food Security}

The United Nations (2017) estimates that by 2030, the world population will grow to 8.3 billion and stabilize at 8.9 billion with the current population momentum.

In order to feed the growing population, the annual world agricultural production must increase by $70 \%$ from 2005 to 2050 (FAO, 2011). A main reason for such a large increase is due to growing meat consumption and the large amounts of crops needed as feedstock (FAO, 2011). Arable land per capita, however, is decreasing as shown in figure 3 and is predicted to fall to less than 0.20 hectares per capita by 2050 which is $1 / 3$ of the arable land in 1970 (FAO, 2011).

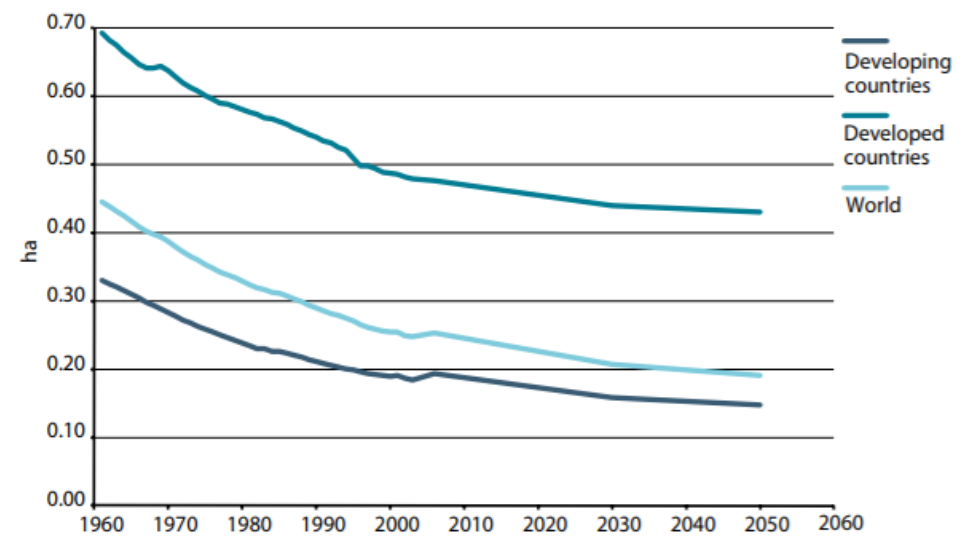

Figure 2. Arable land per capita from 1960 to 2050. Retrieved from FAO (2011)

VF can provide a solution to improve food security as it does not require arable soil for agriculture, can be immune to weather effects (most VFs are indoor farms), and can have multiple times (depending on the height of the facility) the grow-space of traditional farms. 


\subsection{Demand for Local Foods}

The US local food market jumped from $\$ 4$ billion in 2002 to $\$ 12$ billion in 2014 and is expected to grow even faster (Adams and Salois, 2010). In Canada, however, there is a lack of primary production for the local food market due to its production being specialized for the export market (Chinnakonda and Telford, 2007).

VF can provide the primary production that is missing. The major obstacle for providing food for the local market is the lack of access to land due to cost and limited supply from urban planners (Chinnakonda and Telford, 2007). VF does not require arable land and would use only as much land as any factory or warehouse would. VF could easily repurpose abandoned urban buildings such as warehouses for production. As such, VF technology can supply fresh, nutritious and safe food from local farmers to local food markets.

\subsection{Food Safety and Health}

Traditional agriculture faces the challenge of preventing pathogens, pests and weeds from destroying crops and sickening its consumers. VF can mitigate these risks significantly by growing in a controlled environment without soil and in conjunction with positive-pressure ventilation, can effectively reduce contamination of insect pests (Sugiyama et al., 2014).

To mitigate the risk of diseases, pests and weeds, traditional agriculture uses herbicides and pesticides which presents the risk of exposure to consumers and agricultural workers (Damalas and Eleftherohorinos, 2011). This risk would be effectively mitigated in VF due to the reduced or lack of pesticides used.

\subsection{Environmental Implications}

Eutrophication is the excessive growth of phytoplankton often due to nutrient enrichment from fertilizer runoff from traditional agriculture or human/animal waste (Yang et al., 2008). Eutrophication can disrupt aquatic ecosystems and cause mass death of aquatic animals due to lack of dissolved oxygen in water (Yang et al., 2008). The soilless nature of VF omits the need for fertilizers which eliminates the risk of eutrophication caused by traditional agriculture (Benke and Tomkins, 2017).

VF (using hydroponics) also needs 12.5 times less water than traditional agriculture Barbosa et al. (2015). The reduced water use has a large environmental implication as global demands on water is increasing as the global population increases. Agriculture water use accounts for approximately $70 \%$ of the world's freshwater use (United Nations, 2017). Much of which goes to waste due to poor irrigation practices in traditional agriculture (United Nations, 2017).

\section{Film Farming Technology}

Film farming (FF) is a soilless farming system similar to hydroponics. It combines hydrogel and membrane technology to create a "hydromembrane" to cultivate plants (Mori, 2013). The hydromembrane replaces the soil in traditional agriculture and eliminates the associated variability and risks (Mori, 2013).

The hydromembrane allows for plants to absorb nutrient solution while excluding viruses and bacteria that could damage the crop (Mori, 2013). In order to absorb water and nutrients, the plants create an osmolality gap by producing higher concentrations of sugar and amino acids (Mori, 2013).

This, however, slows plant growth and hence lowers productivity. To counteract this, the Imec farming system (designed by Mebiol) supplies small amounts of water to the top/dry layer of the membrane to improve plant growth (Mori, 2013). Furthermore, as shown in figure 4, the Imec system employs a waterproof sheet to prevent water runoff and further reduce risks of viral and bacterial contamination (Mori, 2013).

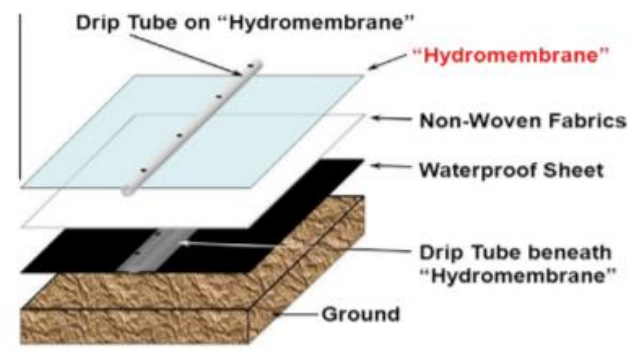

Figure 3. A typical Imec film farming system setup. Retrieved from Mori (2013)

Like VF, FF can be used in traditionally non-arable land as it does not require soil and exhibits reduced water use 
(Mori, 2013).

Used in conjunction with VF, the film can reduce water/nutrient solution use, increase plant nutrition, further mitigate risk of bacterial and viral infection and reduce or eliminate the cost of some of its infrastructure such as racks and water tanks.

\section{Cost/Benefit Analysis}

Entrepreneurs and investors are interested in the break-even point when determining if they should start a vertical farm. The break-event point is the number of years needed from start-up at which the availability of product is no longer hampered by the cost structure (Benke et al., 2016). In other words, the cumulative revenue of the plant matches the total cost of the plant and profit is nil.

\subsection{Expenses and Revenue}

To calculate the breakeven point, the expenses and revenue of an operation is required. Eaves and Eaves (2018) estimated the revenue as well as the capital and operational expenses required for a 6 level, 18000 square feet vertical farm. The farm assumes that $70 \%$ of floor space will be used for growing resulting in 787 grow units available in the facility. The estimated capital expense for the facility was $\$ 587526.72$ and the operational cost was estimated to be $\$ 208382 /$ year (Eaves and Eaves, 2018). The revenue was estimated to be $\$ 476,637 /$ year by assuming 5\% loss during harvest for a total of $67531 \mathrm{~kg}$ harvested and sold at a price of US\$7.62/kg (Eaves and Eaves, 2018).

\subsection{Break-Even Point}

The break-even point was calculated by dividing the fixed costs by the difference between revenue and variable costs. The calculations are shown below.

$$
\text { Breakeven Point }=\frac{\$ 587526.72 / \text { year }}{\$ 476637 / \text { year }-\$ 208382 / \text { year }}=2.19 \text { years }
$$

A break-even point of close to 2 years means that the owner and investors will have to wait at least two years to see a return on investments. This time provides uncertainty to investors and deters new entrepreneurs from entering the market. Reductions in the break-even point by increasing revenue or reducing costs can help improve the viability and sustainability of VFs as businesses.

\subsection{Impact of Film Farming Tech on Cost and Benefit}

Incorporation of FF technology is possible and can improve plant quality and overall yield. Its costs and benefits, however, are unclear. Gokulan (2012) reports the cost of installation of Imec film faming for a one-acre farm is $\$ 2$ million USD and \$2000/acre of film medium.

The proposed VF has a growing area of $18888 \mathrm{ft}^{2}$ which is approximately 0.43361 acres. If the cost of Imec film farming medium and installation is directly scalable to the size of the farm or cultivation area, then the capital cost of such a farm would be $\$ 868$ 087.22 USD (Calculation shown below).

$$
\text { Cost of VF Using Film Farming }=0.43361 \text { acres } * \frac{\$ 2000000+\$ 2000}{\text { acre }}=\$ 868087.22
$$

This is approximately 1.5 times the fixed cost of a regular hydroponics VF and as such, the break-even point would increase to approximately 3 years (1.5 times the break-even point of regular VF).

Assuming the current cost structure, integration of FF is only viable if the added benefit due to increased yield and improved quality (allowing a higher price point) can offset the additional capital expense such that the break-even point remains constant. This added revenue is determined to be $\$ 128$ 131.86/year as shown below. This added revenue can either arise from an increased yield, increase in price or a combination of both.

$$
\begin{gathered}
\text { Breakeven Point }=2.19 \text { years }=\frac{\$ 868087.22 / \text { year }}{\frac{\$(476637+\mathrm{x})}{\text { year }} \$ 208382 / \text { year }}, \text { where } \mathrm{x}=\text { added revenue needed } \\
\mathrm{x}=\$ 128131.86 / \text { year }
\end{gathered}
$$

The increased yield needed to achieve this added revenue while maintaining the same price point is $27247 \mathrm{~kg}$ or $43.57 \%$ increase in yield as shown below. Another option is to increase selling price. The higher price required to reach the higher revenue is calculated as well to be $\$ 9.67 / \mathrm{kg}$ or a $26.90 \%$ price increase. More realistically, a combination of the two is more likely and feasible in the application of FF farming in VF systems.

Total Revenue Needed $=\$ 476637 /$ year $+\$ 128131.86 /$ year $=\$ \mathbf{6 0 4} \mathbf{7 6 8 . 8 6} /$ year 


$$
\begin{gathered}
\text { Increased Yield Needed }=\frac{\$ 208382 / \text { year }}{\$ 7.62 / \mathrm{kg} \text { lettuce }}=27247 \mathrm{~kg} \\
\% \text { yield increase }==\frac{\text { Increased Yield }}{\text { Original Yield }}=\frac{27247 \mathrm{~kg}}{62531 \mathrm{~kg}}=\mathbf{4 3 . 5 7 \%} \\
\text { Price Point Needed }=\frac{\text { Revenue Needed }}{\text { Yield }}=\frac{\$ 604768.86 / \text { year }}{62531 \mathrm{~kg}}=\$ \mathbf{9 . 6 7 / \mathrm { kg }} \\
\% \text { Price increase }=\frac{\text { Increased Price }}{\text { Original Price }}-1=\frac{\$ 9.67 / \mathrm{kg}}{\$ 7.62 / \mathrm{kg}}-1=\mathbf{2 6 . 9 0 \%}
\end{gathered}
$$

\section{Benefits to Plant Yield and Quality}

To evaluate if FF integration is viable, the changes to plant yield and quality must be evaluated because the yield would directly increase revenue whilst an increase plant quality can justify a price premium to increase revenue.

Film farming's largest impact on plant growth is its ability to induce water stress. As such, its effects on plant growth and composition can be best predicted by plant responses to water stress.

\subsection{Plant Yield}

The yield of plants grown using FF will result in lower yield per head as the water stress induced by the hydromembrane will result in a lower dry mass of leaves, stems and roots. This is supported by Omami and Hammes (2006) as the plant dry mass was reduced by $54.2 \%$ for amaranth subjected to water stress.

The size of the lettuce leaf is expected to be reduced in FF as an adaptation to the water stress as seen in Omami and Hammes (2006) when amaranth subjected to water stress had the smallest leaf area at 36\% of the control. As the size of the individual plants are lower, plants would be able to be planted at higher concentrations. As such, the overall yield per growing area is expected to increase such that it offsets the lower individual yield.

\subsection{Plant Quality}

The leaves of plants grown using FF are expected to have a lesser green hue due to the loss of chlorophyll in response to water stress. This is due to the initiation of early leaf senescence (final stage of leaf development) in order to degrade chloroplast and recycle nitrogen into the flower and seeds for early flowering (Wang and Blumwald, 2014).

The water content of plants grown with FF is expected to be reduced and the proximate composition is expected to show a higher carbohydrate and mineral content as plants respond to water stress by producing more soluble sugars (especially sucrose) and accumulate more minerals (Pelah et al., 1997).

Plants grown using FF are expected to have higher amino acid content, specifically proline (Mundim and Pringle, 2018). The high proline content is expected due to its important functions as an osmolyte, a metal chelator, an antioxidant and as a signaling molecule during water stress (Hayat et al., 2012).

Total dietary fibre is expected to increase as demonstrated in red beets by Stagnari et al. (2014) and in Amaranthus tricolor by Sarker et al., (2018). Vitamin C, beta-carotene, flavanols, caffeic acid and its derivatives are expected to increase as well in order to quench the reactive oxygen species generated by the destruction of chlorophyll in water stressed conditions (Oh et al., 2010). This leads to an expected increase in antioxidant activity as well.

Phenolics are expected to increase as well and has been associated with proline metabolism and its function as antioxidants (Mundim and Pringle, 2018). Tannins and especially flavonoid tannins are implicated in plant drought resistance as their structure protects plant cell walls from cracking (Pizzi and Cameron, 1986). Terpenoids are also shown to impart drought resistance to plants such as maize (Zerbe, 2015).

\subsection{Significance}

The changes in plant yield and quality directly affects the supply and price of lettuce from the farm. The decreased individual plant yield expected may be discouraging but the reduction in leaf size would allow for more concentrated planting to offset the decrease. The reduction in vegetative growth, however, is accompanied with a shift of focus to plant reproductive growth. As such, this application may have potential in increasing yield in plants such as tomatoes, saffron and edible flowers due to the value of their fruit and flowers.

The expected increase in all nutrients of interest can provide justification for the increase in price of lettuce. These findings along with the increased food safety and sustainability of the vertical farming model provides credibility in the products claims to be disruptive in the food market and allows for a price premium to be commanded.

Subjective knowledge is shown to affect consumer consumption of organic foods and by extension this could 
apply to produce from VF and FF. Promotion of the benefits of VF and FF will therefore be needed in order to demand such a price premium (Chang and Zepeda, 2005). The reduced green hue of the leaves may, however, negatively influence public perception of the produce's freshness and quality.

\section{Conclusion}

VF can be a part of the solution to global food security due to its efficient land use and ecological sustainability. When integrated with FF, there would be improvements that allow for a superior product to be produced while using less water and improving the safety of the produce. A cost-benefit analysis based on a hypothetical farm by Eaves and Eaves (2018) determined that a yield increase of $27247 \mathrm{~kg}(43.57 \%)$ and a price point of $\$ 9.67 / \mathrm{kg}$ (26.90\% increase) are needed for FF integration to be viable. A review of articles regarding plants grown under water stress - similar to what would be induced by FF — showed reduced individual plant yield and reduced leaf size while nutrient contents will be improved across the board. The results would show that FF integration in VF is viable as it can provide the plant quality improvements necessary to demand the price premium or the improved yield needed.

\section{References}

Adams, D. C., \& Salois, M. J. (2010). Local versus organic: A turn in consumer preferences and willingness-to-pay. Renewable Agriculture and Food Systems, 25(4), 331-341. https://doi.org/10.1017/S1742170510000219

Al-Kodmany, K. (2018). The Vertical Farm: A Review of Developments and Implications for the Vertical City. Buildings, 8(2), 24. https://doi.org/10.3390/buildings8020024

Barbosa, G. L., Gadelha, F. D. A., Kublik, N., Proctor, A., Reichelm, L., Weissinger, E., ... Halden, R. U. (2015). Comparison of Land, Water, and Energy Requirements of Lettuce Grown Using Hydroponic vs. Conventional Agricultural Methods. International Journal of Environmental Research and Public Health, 12(6), 6879-6891. https://doi.org/10.3390/ijerph120606879

Bates, L. S., Waldren, R. P., \& Teare, I. D. (1973). Rapid determination of free proline for water-stress studies. Plant and Soil, 39(1), 205-207. https://doi.org/10.1007/BF00018060

Benke, K., \& Tomkins, B. (2017). Future food-production systems: vertical farming and controlled-environment agriculture. Sustainability: Science, Practice and Policy, 13(1), 13-26. https://doi.org/10.1080/15487733.2017.1394054

Besseau, S., Hoffmann, L., Geoffroy, P., Lapierre, C., Pollet, B., \& Legrand, M. (2007). Flavonoid Accumulation in Arabidopsis Repressed in Lignin Synthesis Affects Auxin Transport and Plant Growth. The Plant Cell Online, 19(1), 148-162. https://doi.org/10.1105/tpc.106.044495

Chang, H.-S., \& Zepeda, L. (2005). Consumer perceptions and demand for organic food in Australia: Focus group discussions. Renewable Agriculture and Food Systems, 20(03), 155-167. https://doi.org/10.1079/RAF2004103

Chinnakonda, D., \& Telford, L. (2007). Local and Regional Food Economies in Canada: Status Report. https://doi.org/S0048-9697(02)00036-0

Damalas, C. A., \& Eleftherohorinos, I. G. (2011). Pesticide exposure, safety issues, and risk assessment indicators. International Journal of Environmental Research and Public Health, 8(5), 1402-1419. https://doi.org/10.3390/ijerph8051402

Diver, S. (2006). Aquaponics-Integration of Hydroponics with Aquaculture. Retrieved from www.aqua.ait.ac.th/

Eaves, J., \& Eaves, S. (2018). Comparing the Profitability of a Greenhouse to a Vertical Farm in Quebec. Canadian Journal of Agricultural Economics/Revue Canadienne d'agroeconomie, 66(1), 43-54. https://doi.org/10.1111/cjag.12161

FAO. (2011). Looking Ahead in World Food and Agriculture: Perspectives to 2050.

Gokulan, D. (2012, March 15). Is future in film farming? Khaleej Times.

Hayat, S., Hayat, Q., Alyemeni, M. N., Wani, A. S., Pichtel, J., \& Ahmad, A. (2012, November). Role of proline under changing environments: A review. Plant Signaling and Behavior, 7(11), 1456-1466. https://doi.org/10.4161/psb.21949

Ilaslan, G., White, G. B., \& Langhans, R. W. (2002). Insights Into the Economic Viability of a New Cea System Producing Hydroponic Lettuce. Staff Paper, February, 19. Retrieved from 
http://publications.dyson.cornell.edu/research/researchpdf/sp/2002/Cornell_Dyson_sp0203.pdf

Kozai, T., Niu, G., \& Takagaki, M. (2016). Plant Factory: An Indoor Vertical Farming System for Efficient Quality Food Production. https://doi.org/10.1017/CBO9781107415324.004

Llorach, R., Martínez-Sánchez, A., Tomás-Barberán, F. A., Gil, M. I., \& Ferreres, F. (2008). Characterisation of polyphenols and antioxidant properties of five lettuce varieties and escarole. Food Chemistry, 108(3), 1028-1038. https://doi.org/10.1016/J.FOODCHEM.2007.11.032

Mori, Y. (2013, July 1). New agro-technology (Imec) by hydrogel membrane. Reactive and Functional Polymers, 73(7), 936-938. https://doi.org/10.1016/j.reactfunctpolym.2012.11.015

Mundim, F. M., \& Pringle, E. G. (2018). Whole-Plant Metabolic Allocation Under Water Stress. Frontiers in Plant Science, 9, 852. https://doi.org/10.3389/fpls.2018.00852

Nguyen, N. T., McInturf, S. A., \& Mendoza-Cózatl, D. G. (2016). Hydroponics: A Versatile System to Study Nutrient Allocation and Plant Responses to Nutrient Availability and Exposure to Toxic Elements. Journal of Visualized Experiments, 113, 54317. https://doi.org/10.3791/54317

Nozzi, V., Graber, A., Schmautz, Z., Mathis, A., \& Junge, R. (2018). Nutrient Management in Aquaponics: Comparison of Three Approaches for Cultivating Lettuce, Mint and Mushroom Herb. Agronomy, 8(3), 27. https://doi.org/10.3390/agronomy8030027

Oh, M.-M., Carey, E. E., \& Rajashekar, C. B. (2019). Regulated Water Deficits Improve Phytochemical Concentration in Lettuce. Journal of the American Society for Horticultural Science, 135.

Omami, E. N., \& Hammes, P. S. (2006). Interactive effects of salinity and water stress on growth, leaf water relations, and gas exchange in amaranth (Amaranthus spp.). New Zealand Journal of Crop and Horticultural Science, 34(1), 33-44. https://doi.org/10.1080/01140671.2006.9514385

Pelah, D., Wang, W., Altman, A., Shoseyov, O., \& Bartels, D. (1997). Differential accumulation of water stress-related proteins, sucrose synthase and soluble sugars in Populus species that differ in their water stress response. Physiologia Plantarum, 99(1), 153-159. https://doi.org/10.1034/j.1399-3054.1997.990121.x

Pizzi, A., \& Cameron, F. A. (1986). Flavonoid tannins - structural wood components for drought-resistance mechanisms of plants. Wood Science and Technology, 20(2), 119-124. https://doi.org/10.1007/BF00351023

Primary Principles. (2015). Primary Principles of Closed Hydroponics. Retrieved from https://sites.google.com/site/sustainablehydroponics/closed-hydroponics

Sarker, U. I., Tofazzal Islam, M. I., \& Oba, S. (2018). Salinity stress accelerates nutrients, dietary fiber, minerals, phytochemicals and antioxidant activity in Amaranthus tricolor leaves. PLoS ONE, 13(11), e0206388. https://doi.org/10.1371/journal.pone.0206388

Stagnari, F., Galieni, A., Speca, S., \& Pisante, M. (2014). Water stress effects on growth, yield and quality traits of red beet. Scientia Horticulturae, 165, 13-22. https://doi.org/10.1016/J.SCIENTA.2013.10.026

Sugiyama, K., Ohishi, N., \& Saito, T. (2014). Preliminary evaluation of greenhouses employing positive-pressure forced ventilation to prevent invasion by insect pests. Applied Entomology and Zoology, 49(4), 553-559. https://doi.org/10.1007/s13355-014-0285-8

United Nations. (2015). A Post-2015 Global Goal for Water: Synthesis of key findings and recommendations from $\mathrm{UN}$-water. Retrieved from http://www.zaragoza.es/contenidos/medioambiente/onu/1090-eng_A_Post-2015_Global_Goal_for_Water.pdf

United Nations. (2017). The Impact of Population Momentum on Future Population Growth.

Wang, S., \& Blumwald, E. (2014). Stress-induced chloroplast degradation in Arabidopsis is regulated via a process independent of autophagy and senescence-associated vacuoles. The Plant Cell, 26(12), 4875-4888. https://doi.org/10.1105/tpc.114.133116

Yang, X., Wu, X., Hao, H., \& He, Z. (2008). Mechanisms and assessment of water eutrophication. Journal of Zhejiang University SCIENCE B, 9(3), 197-209. https://doi.org/10.1631/jzus.B0710626

Zerbe, P. (2015). Small molecules with big impact: Terpenoid phytoalexins as key factors in maize stress tolerance. Plant, Cell and Environment, 38(11), 2193-2194. https://doi.org/10.1111/pce.12523 


\section{Copyrights}

Copyright for this article is retained by the author(s), with first publication rights granted to the journal.

This is an open-access article distributed under the terms and conditions of the Creative Commons Attribution license (http://creativecommons.org/licenses/by/3.0/). 